\title{
Recent changes of suspended sediment yields in the Upper Yangtze River and its headwater tributaries
}

\author{
XINBAO ZHANG ${ }^{1}$, QIANG TANG ${ }^{1,2}$, YI LONG ${ }^{1}$, XIUBIN HE ${ }^{1}$ \& ANBANG WEN ${ }^{1}$ \\ 1 Key Laboratory of Mountain Surface Processes and Ecological Regulation, Institution of Mountain Hazards and \\ Environment, Chinese Academy of Sciences, Chengdu 610041, China \\ zxbao@imde.ac.cn \\ 2 University of Chinese Academy of Sciences, Beijing 100049, China
}

\begin{abstract}
Suspended sediment yields in the Upper Yangtze River and its four headwater tributaries (i.e. Jinsha, Min, Jialing and $\mathrm{Wu}$ ) have declined significantly during recent decades. Compared with 1956-1970, mean annual suspended sediment yield during 2001-2011 was reduced by $84 \%$ in the Upper Yangtze River at Yichang, by $34 \%$ in the Jinsha at Pingshan, by $84 \%$ in the Jialing at Beibei, by $75 \%$ in the Wu at Wulong, and by $48 \%$ in the Min at Gaochang. Linking these observed decadal changes of runoff discharge and suspended sediment load to dam construction and multiple environmental rehabilitation projects (e.g. soilwater conservation, reforestation) during the past decades, it can be concluded that the construction of large dams on the main stem and major tributaries of the Upper Yangtze River has played a principal role in the reduction of fluvial suspended sediment yields, while the environment rehabilitation projects may make limited contributions to the changes in suspended sediment yields, except for the Jialing River.
\end{abstract}

Key words runoff discharge; suspended sediment yield; dam construction; environmental rehabilitation; Upper Yangtze River; Three Gorges Reservoir

\section{INTRODUCTION}

The Upper Yangtze River Basin has been targeted as a principal provenance area for runoff discharge and suspended sediment yield in the Yangtze River. However, suspended sediment yields in the Upper Yangtze River and its major headwater tributaries (i.e. Jinsha, Jialing, Min and $\mathrm{Wu}$ ) have demonstrated continuous reduction over the past decades (Zhang and Wen, 2004; Lin et al., 2010). Much literature has attempted to link these temporal changes to climate change (e.g. the change of precipitation, air temperature and evaporation) and the expansion and intensification of diverse human activities (e.g. extensive land-use change associated with forest destruction, land clearance and agricultural expansion and intensification, water diversion, soil and water conservation, sand dredging, flood-plain deposition and channel erosion, dam construction, urbanization, mining and infrastructure construction) (Walling and Fang, 2003; Dai et al., 2008). However, the response of fluvial suspended sediment yields has become even more complicated recently due to diverse human disturbances. The present paper attempts to detect the recent changes of suspended sediment yields in the Upper Yangtze River and its four headwater tributaries using the recent datasets recorded at the key hydrometric stations in this region, and analyses the potential effects of dam construction and environmental rehabilitation projects on these temporal changes in suspended sediment yields.

\section{STUDY AREA}

The Upper Yangtze River has a total drainage area of $1.005 \times 10^{6} \mathrm{~km}^{2}$ and encompasses four major headwater tributaries including the Jinsha with a catchment area of $48.5 \times 10^{4} \mathrm{~km}^{2}$, the Jialing $\left(15.6 \times 10^{4} \mathrm{~km}^{2}\right)$, the Min $\left(13.5 \times 10^{4} \mathrm{~km}^{2}\right)$ and the $\mathrm{Wu}\left(8.3 \times 10^{4} \mathrm{~km}^{2}\right)$. The four major tributaries have a total area of $88.3 \times 10^{4} \mathrm{~km}^{2}$, which accounts for $87.9 \%$ of the catchment area of the Upper Yangtze River. Mean annual runoff discharge and suspended sediment yield during $1956-2011$ were $4260 \times 10^{8} \mathrm{~m}^{3}$ and $4.20 \times 10^{8} \mathrm{t}$ for the Upper Yangtze River, $1428 \times 10^{8} \mathrm{~m}^{3}$ and $1.03 \times 10^{8} \mathrm{t}$ for the Jinsha, $2.36 \times 10^{8} \mathrm{~m}^{3}$ and $847 \times 10^{8} \mathrm{t}$ for the Jialing, $652 \times 10^{8} \mathrm{~m}^{3}$ and $0.45 \times$ $10^{8} \mathrm{t}$ for the Min, and $485 \times 10^{8} \mathrm{~m}^{3}$ and $0.24 \times 10^{8} \mathrm{t}$ for the $\mathrm{Wu}$ (Table 1). The Upper Yangtze River Basin has a specific sediment yield of $418 \mathrm{t} \cdot \mathrm{km}^{-2} \cdot \mathrm{year}^{-1}$. The Jialing catchment has the highest specific sediment yield of $660 \mathrm{t} \cdot \mathrm{km}^{-2}$. year ${ }^{-1}$ due to widespread loess deposits in the upper reaches, while the Jinsha has moderate specific sediment yield of $487 \mathrm{t} \cdot \mathrm{km}^{-2}$.year ${ }^{-1}$ due to its 


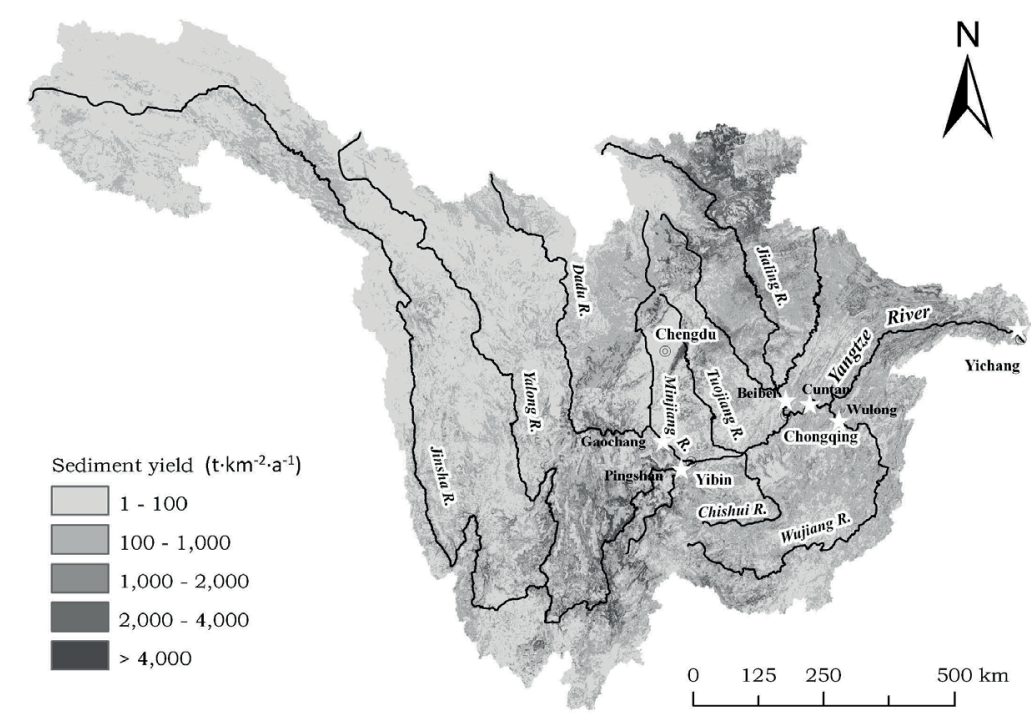

Fig. 1 A sketch map of the Upper Yangtze River Basin with specific sediment yields and the locations of key hydrometric stations.

Table 1 Decadal changes of mean annual runoff discharge, suspended sediment yield and silt content in the Upper Yangtze River and its four headwater tributaries.

\begin{tabular}{|c|c|c|c|c|c|c|c|}
\hline \multirow{2}{*}{$\begin{array}{l}\text { River } \\
\text { (hydro-station) }\end{array}$} & \multirow{2}{*}{$\begin{array}{l}\text { Area } \\
\left(\times 10^{4}\right. \\
\left.\mathrm{km}^{2}\right)\end{array}$} & \multicolumn{6}{|c|}{ Mean annual discharge $\left(\times 10^{8} \mathrm{~m}^{3}\right) /$ Mean annual suspended sediment yield $\left(\times 10^{8} \mathrm{t}\right) /$ silt content $\left(\mathrm{kg} \cdot \mathrm{m}^{-3}\right)$} \\
\hline & & 1956-2011 & $1956-1970$ & $1971-1980$ & $1981-1990$ & $1991-2000$ & $2001-2011$ \\
\hline $\begin{array}{l}\text { Upper Yangtze } \\
\text { (Yichang) }\end{array}$ & 100.5 & $\begin{array}{l}4260(424 \mathrm{~mm}) / \\
4.20(418 \\
\left.\mathrm{t} / \mathrm{km}^{2} \cdot \mathrm{a}\right) / 0.99\end{array}$ & $\begin{array}{l}4387(437 \mathrm{~mm}) / \\
5.45 \\
\left(542 \mathrm{t} / \mathrm{km}^{2} \cdot \mathrm{a}\right) / 1.24\end{array}$ & $\begin{array}{l}4187(417 \mathrm{~mm}) / \\
4.80 \\
\left(478 \mathrm{t} / \mathrm{km}^{2} \cdot \mathrm{a}\right) / 1.15\end{array}$ & $\begin{array}{l}4433(441 \mathrm{~mm}) / \\
5.41 \\
\left(538 \mathrm{t} / \mathrm{km}^{2} \cdot \mathrm{a}\right) / 1.22\end{array}$ & $\begin{array}{l}4336(431 \mathrm{~mm}) / \\
4.17 \\
\left(415 \mathrm{t} / \mathrm{km}^{2} \cdot \mathrm{a}\right) / 0.96\end{array}$ & $\begin{array}{l}3929(391 \mathrm{~mm}) / \\
0.88 \\
\left(88 \mathrm{t} / \mathrm{km}^{2} \cdot \mathrm{a}\right) / 0.22\end{array}$ \\
\hline $\begin{array}{l}\text { Upper Yangtze } \\
\text { (Cuntan) }\end{array}$ & 86.7 & $\begin{array}{l}3395(392 \mathrm{~mm}) / \\
3.90(450 \\
\left.\mathrm{t} / \mathrm{km}^{2} \cdot \mathrm{a}\right) / 1.15\end{array}$ & $\begin{array}{l}3564(411 \mathrm{~mm}) / \\
4.85 \\
\left(559 \mathrm{t} / \mathrm{km}^{2} \cdot \mathrm{a}\right) / 1.36\end{array}$ & $\begin{array}{l}3265(377 \mathrm{~mm}) / \\
3.83\left(442 \mathrm{t} / \mathrm{km}^{2} \cdot \mathrm{a}\right) / \\
1.17\end{array}$ & $\begin{array}{l}3535(408 \mathrm{~mm}) / \\
4.77\left(550 \mathrm{t} / \mathrm{km}^{2} \cdot \mathrm{a}\right) / \\
1.35\end{array}$ & $\begin{array}{l}3310(382 \mathrm{~mm}) / \\
3.83\left(442 \mathrm{t} / \mathrm{km}^{2} \cdot \mathrm{a}\right) / \\
1.16\end{array}$ & $\begin{array}{l}3230(373 \mathrm{~mm}) / \\
1.98\left(228 \mathrm{t} / \mathrm{km}^{2} \cdot \mathrm{a}\right) / \\
0.61\end{array}$ \\
\hline $\begin{array}{l}\text { Jinsha } \\
\text { (Pingsha) }\end{array}$ & 48.5 & $\begin{array}{l}1428(294 \mathrm{~mm}) / \\
2.36(487 \\
\left.\mathrm{t} / \mathrm{km}^{2} \cdot \mathrm{a}\right) / 1.65\end{array}$ & $\begin{array}{l}1457(300 \mathrm{~mm}) / \\
2.47 \\
\left(509 \mathrm{t} / \mathrm{km}^{2} \cdot \mathrm{a}\right) / 1.70\end{array}$ & $\begin{array}{l}1342(277 \mathrm{~mm}) / \\
2.21 \\
\left(456 \mathrm{t} / \mathrm{km}^{2} \cdot \mathrm{a}\right) / 1.65\end{array}$ & $\begin{array}{l}1419(293 \mathrm{~mm}) / \\
2.63 \\
\left(542 \mathrm{t} / \mathrm{km}^{2} \cdot \mathrm{a}\right) / 1.85\end{array}$ & $\begin{array}{l}1483(306 \mathrm{~mm}) / \\
2.95 \\
\left(608 \mathrm{t} / \mathrm{km}^{2} \cdot \mathrm{a}\right) / 1.99\end{array}$ & $\begin{array}{l}1423(293 \mathrm{~mm}) / \\
1.54 \\
\left(318 \mathrm{t} / \mathrm{km}^{2} \cdot \mathrm{a}\right) / 1.08\end{array}$ \\
\hline $\begin{array}{l}\text { Jialing } \\
\text { (Beibei) }\end{array}$ & 15.6 & $\begin{array}{l}652(418 \mathrm{~mm}) / \\
1.03(660 \\
\left.\mathrm{t} / \mathrm{km}^{2} \cdot \mathrm{a}\right) / 1.58\end{array}$ & $\begin{array}{l}712(456 \mathrm{~mm}) / \\
1.69 \\
\left(1083 \mathrm{t} / \mathrm{km}^{2} \cdot \mathrm{a}\right) / 2.37\end{array}$ & $\begin{array}{l}617(396 \mathrm{~mm}) / \\
1.12 \\
\left(718 \mathrm{t} / \mathrm{km}^{2} \cdot \mathrm{a}\right) / 1.82\end{array}$ & $\begin{array}{l}762(488 \mathrm{~mm}) / \\
1.36 \\
\left(872 \mathrm{t} / \mathrm{km}^{2} \cdot \mathrm{a}\right) / 1.78\end{array}$ & $\begin{array}{l}533(342 \mathrm{~mm}) / \\
0.45 \\
\left(288 \mathrm{t} / \mathrm{km}^{2} \cdot \mathrm{a}\right) / 0.84\end{array}$ & $\begin{array}{l}610(391 \mathrm{~mm}) / \\
0.30 \\
\left(192 \mathrm{t} / \mathrm{km}^{2} \cdot \mathrm{a}\right) / 0.49\end{array}$ \\
\hline $\begin{array}{l}\text { Min } \\
\text { (Gaochang) }\end{array}$ & 13.5 & $\begin{array}{l}847(627 \mathrm{~mm}) / \\
0.45(333 \\
\left.\mathrm{t} / \mathrm{km}^{2} \cdot \mathrm{a}\right) / 0.53\end{array}$ & $\begin{array}{l}887(657 \mathrm{~mm}) / \\
0.58 \\
\left(430 \mathrm{t} / \mathrm{km}^{2} \cdot \mathrm{a}\right) / 0.65\end{array}$ & $\begin{array}{l}834(618 \mathrm{~mm}) / \\
0.34 \\
\left(252 \mathrm{t} / \mathrm{km}^{2} \cdot \mathrm{a}\right) / 0.41\end{array}$ & $\begin{array}{l}908(673 \mathrm{~mm}) / \\
0.62 \\
\left(459 \mathrm{t} / \mathrm{km}^{2} \cdot \mathrm{a}\right) / 0.68\end{array}$ & $\begin{array}{l}824(610 \mathrm{~mm}) / \\
0.36 \\
\left(267 \mathrm{t} / \mathrm{km}^{2} \cdot \mathrm{a}\right) / 0.44\end{array}$ & $\begin{array}{l}771(571 \mathrm{~mm}) / \\
0.30 \\
\left(222 \mathrm{t} / \mathrm{km}^{2} \cdot \mathrm{a}\right) / 0.39\end{array}$ \\
\hline $\begin{array}{l}\text { Wu } \\
\text { (Wulong) }\end{array}$ & 8.3 & $\begin{array}{l}485(584 \mathrm{~mm}) / \\
0.24(289 \\
\left.\mathrm{t} / \mathrm{km}^{2} \cdot \mathrm{a}\right) / 0.49\end{array}$ & $\begin{array}{l}483(582 \mathrm{~mm}) / \\
0.28 \\
\left(337 \mathrm{t} / \mathrm{km}^{2} \cdot \mathrm{a}\right) / 0.58\end{array}$ & $\begin{array}{l}520(627 \mathrm{~mm}) / \\
0.40\left(482 \mathrm{t} / \mathrm{km}^{2} \cdot \mathrm{a}\right) / \\
0.77\end{array}$ & $\begin{array}{l}455(548 \mathrm{~mm}) / \\
0.23\left(277 \mathrm{t} / \mathrm{km}^{2} \cdot \mathrm{a}\right) / \\
0.51\end{array}$ & $\begin{array}{l}538(648 \mathrm{~mm}) / \\
0.22\left(265 \mathrm{t} / \mathrm{km}^{2} \cdot \mathrm{a}\right) / \\
0.41\end{array}$ & $\begin{array}{l}433(522 \mathrm{~mm}) / \\
0.07 \\
\left(84 \mathrm{t} / \mathrm{km}^{2} \cdot \mathrm{a}\right) / 0.16\end{array}$ \\
\hline
\end{tabular}

deeply dissected terrain and active fault zones in the lower reaches. The Wu River has the lowest specific sediment yield of $280 \mathrm{t} \cdot \mathrm{km}^{-2} \cdot$ year $^{-1}$ (Fig. 1).

Since the 1950s, multiple hydrology-related human activities have taken place across the Upper Yangtze River Basin. The campaign of the Great Leap Forward and People's Commune during the 1950s and 1960s had led to extensive deforestation. However, a huge number of ponds and small-medium sized reservoirs were also constructed. Since the late 1970s, great social and economic changes have occurred in the rural communities and farmers have been given independent rights on land management. Overall income and living conditions have been improved, and energy from coal has replaced the need for harvesting forests and grasslands for timber and fuel. Birth control policy has also effectively reduced the rate of population growth. Two important environmental rehabilitation projects have been undertaken in the Upper Yangtze 
River Basin since 1989. One is 'the State Key Soil and Conservation Project in the Upper Yangtze River', launched in 1989 for protection of the Three Gorges Reservoir from sedimentation. Another is 'the Natural Forest Protection Project' which was launched in 1999. Large reservoirs on the main stem of the Upper Yangtze River and its tributaries have been constructed since 1970. The Gongzui Reservoir on the Min River was the first, and was completed in 1970.

\section{RESULTS AND DISCUSSION}

\section{Recent changes of water discharge and suspended sediment yields}

The Jinsha River (Pingshan) Annual runoff discharge in the Jinsha recorded at Pingshan shows normal variation during the past decades (Fig. 2) and the decadal mean annual values varies from 1342 to $1457 \times 10^{8} \mathrm{~m}^{3}$ (Table 1). Silt content had normal variation during 1956-1980 with a mean value of $1.69 \mathrm{~kg} \cdot \mathrm{m}^{-3}$ during $1956-1970$ and $1.65 \mathrm{~kg} \cdot \mathrm{m}^{-3}$ during $1971-1980$. But it increased significantly during $1981-2011$ from a mean values of $1.85 \mathrm{~kg} \cdot \mathrm{m}^{-3}$ for $1981-1990$ and $1.99 \mathrm{~kg} \cdot \mathrm{m}^{-3}$ for 1991-2000 to $1.08 \mathrm{~kg} \cdot \mathrm{m}^{-3}$ during 2001-2011. Decline of sediment yield has occurred since the operation of the Ertan Reservoir on the lower reaches of the Yalong River (a major tributary of the Jinsha) (Fig. 2).
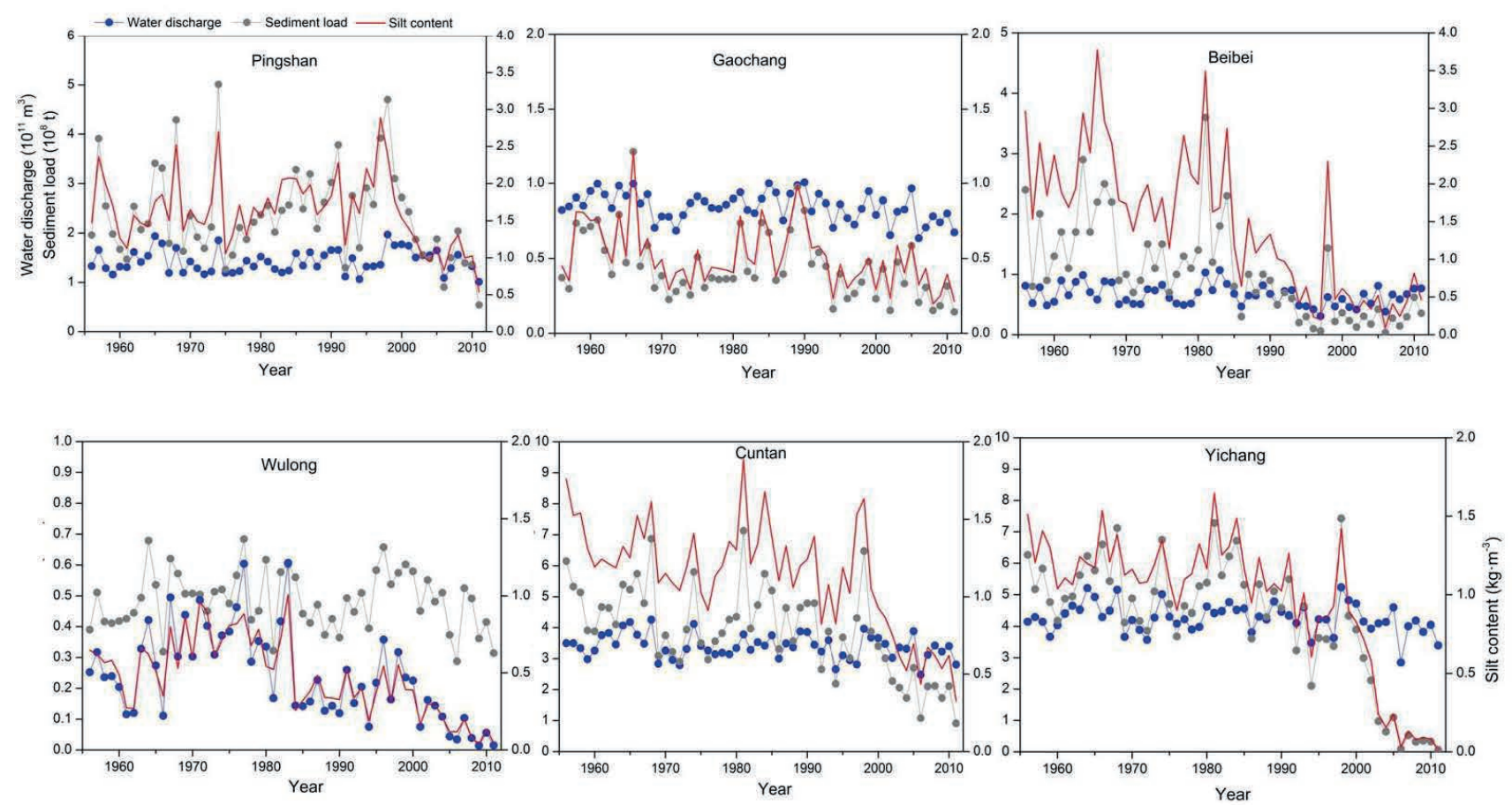

Fig. 2 The inter-annual variations of runoff discharge, sediment yield and silt content in Upper Yangtze River and its four major tributaries.

Massive deforestation during the 1950s-1960s did not trigger an immediate response of sediment yield observed at Pingshan, which probably was due to the channel buffering effects on sediment transport. The slight increase of silt contents during the period of 1980-2000 was probably caused by deforestation and the large-scale infrastructure construction along the river sides, including railways, roads, mining and towns. Since the mid-1960s, it is obvious that Ertan Reservoir played an essential role in reducing sediment load since 1999. Besides the welldocumented mechanism of reservoirs in trapping sediment, reduction of in-stream sediment transportation capacity by Ertan Reservoir during major floods resulting from water impoundment played an important role in riverine sediment regulation in the lower Jinsha River. Sediment reduction within the reaches below a dam is usually less than the sediment load trapped for the downstream river, with no or limited sediment supply from tributaries after reservoir operation 
(Fig. 3(a) and (b)). However, the reduction may be larger than the sediment load trapped in the reservoir for the downstream river has a huge sediment supply from tributaries (e.g. the lower Jinsha River) after the operation (Fig. 3(c)). The mean annual sediment yield at the Pingshan was $2.95 \times 10^{8} \mathrm{t}$ during 1991-2000 and $1.54 \times 10^{8} \mathrm{t}$ during 2001-2011. The reduction of $1.41 \times 10^{8}$ $\mathrm{t} \cdot$ year ${ }^{-1}$ was greater than the $0.27 \times 10^{8} \mathrm{t}^{-} \mathrm{year}^{-1}$ of mean annual inflow sediment yield into the Ertan Reservoir. It strongly indicates that the reduction of in-stream sediment transportation capacity by Ertan Reservoir has played a key role in reduction of sediment yields at Pingshan since 1999. The construction of Xiluodu dam in 2007 has made a certain contribution to the reduction of sediment yields. The hydrological data did not show any clear influences of the two important environmental rehabilitation projects on sediment yields in the Jinsha River basin. It is suggested that environmental rehabilitation has a long-term influence on sediment yields in a river and is not easily demonstrated from short-term of hydrological data, or that the influence is much less than for big dams over a short time-scale.

The Jialing River The mean annual runoff discharge is $652 \times 10^{8} \mathrm{~m}^{3}$ and the highest value of $762 \times 10^{8} \mathrm{~m}^{3}$ occurred during 1971-1980. Since then, it seems to have a decreasing tendency with the lowest value of $533 \times 10^{8} \mathrm{~m}^{3}$ during 1991-2000 (Table 1). It is probably caused by both the climate changes (significant rise of temperature and slight fall of precipitation) and the increased water usage, both irrigation and non-irrigation. The highest silt concentration of $2.37 \mathrm{~kg} \cdot \mathrm{m}^{-3}$ occurred during 1956-1970. Since then, it has continuously decreased, particularly since the $1990 \mathrm{~s}$, and the concentration was only $0.49 \mathrm{~kg} \cdot \mathrm{m}^{-3}$ during 2001-2011. No doubt the decrease of sediment load since the 1970 s is mainly owing to human activities, both land-use changes and a huge number of various reservoirs and ponds in the basin. However, the rapid decrease of sediment load since the 1980s is apparently caused by the big reservoirs on the main stream, such as Bikou, Baozhushi and Dongxiguan reservoirs.

The Min River The mean annual runoff discharge is $847 \times 10^{8} \mathrm{~m}^{3}$ and the highest value of $908 \times 10^{8} \mathrm{~m}^{3}$ occurred during 1971-1980. Since then, it seems to have a decreasing tendency with the lowest value of $771 \times 10^{8} \mathrm{~m}^{3}$ during 2001-2000 (Table 1). It is probably caused by both the climate change (significant rise of temperature and slight fall of precipitation). The mean silt concentration is $0.53 \mathrm{~kg} \cdot \mathrm{m}^{-3}$ during 1956-2011 and the highest and lowest annual values of 1.22 and $0.20 \mathrm{~kg} \cdot \mathrm{m}^{-3}$ occurred in 1996 and 2008, respectively (Fig. 2). The annual sediments yield and mean silt concentration have obviously fluctuated but there was no systematic trend before closure of the Pubugou Reservoir dam (storage volume of $51.77 \times 10^{8} \mathrm{~m}^{3}$ ) in 2005 (Fig. 2). From the double accumulative curve, two turning points can be discerned in 1970 and 1993, which correspond quite well to the operation of the Gongzui Reservoir with a storage volume of $3.74 \times 10^{8} \mathrm{~m}^{3}$ in 1970 and of the Tongjiezi Reservoir $\left(2.0 \times 10^{8} \mathrm{~m}^{3}\right.$ in 1993). Since 2006, sediment load has significantly decreased and the mean annual sediment yield and silt concentration for the period of 2006-2011 were $0.22 \times 10^{8} \mathrm{t} \cdot$ year ${ }^{-1}$ and $0.30 \mathrm{~kg} \cdot \mathrm{m}^{-3}$, accounting for $49 \%$ and $57 \%$ of the values, respectively, for 1956-2011. It is clear that the trapping of sediment by the Tongjiezi Reservoir had a great impact on the sediment load in Min River at Gaochang. No increase of sediment yield and silt concentration since 2008 indicates that the big Wenchuan earthquake that occurred in the basin had little effect on the sediment load in the river.

The Wu River Annual discharge has normal variation for the last five decades (Fig. 2) and the decadal mean values vary from 433 to $538 \times 10^{8} \mathrm{~m}^{3}$ (Table 1). Mean silt concentration increased from $0.58 \mathrm{~kg} \cdot \mathrm{m}^{-3}$ during $1956-1970$ to $0.77 \mathrm{~kg} \cdot \mathrm{m}^{-3}$ during $1971-1980$, then continuously decreased to $0.16 \mathrm{~kg} \cdot \mathrm{m}^{-3}$ during 2001-2011 (Table 1). It is suggested that the increase of sediment load before 1980 was caused by deforestation since the late of 1950s and by the lack of small and medium sized reservoirs and ponds to trap sediments because of the karst landforms in the basin. The continuous decrease of sediment load since 1980 is clearly due to operation of large reservoirs (e.g. Wujiangdu, Suofengying and Dongfeng) on the Wu River main stream. 
The Upper Yangtze River Mean annual runoff discharge in the Upper Yangtze River recorded at Yichang is $4342 \times 10^{8} \mathrm{~m}^{3}$ for the period 1956-2000 and decreased to $3929 \times 10^{8} \mathrm{~m}^{3}$ for the period 2001-2011. This decrease is probably mainly attributed to climate change (increased temperature and decreased precipitation). Silt concentration and sediment yield had normal variation with mean values $1.15 \mathrm{~kg} \cdot \mathrm{m}^{-3}$ and $4.94 \times 10^{8} \mathrm{t} \cdot \mathrm{year}^{-1}$, respectively. However, those mean values dramatically dropped to $0.22 \mathrm{~kg} \cdot \mathrm{m}^{-3}$ and $0.88 \times 10^{8} \mathrm{t} \cdot$ year ${ }^{-1}$, respectively, for the period 2001-2011. Since 1999, sediment yield has significantly deceased because of the sudden drop of the yield from Jinsha River due to the Ertan Reservoir. However, severe decrease has occurred since 2003 when the first-phase of the Three Gorges Project started operation and annual sediment yield ranged between only 0.06 and $1.10 \times 10^{8} \mathrm{t}^{\cdot}$ year $^{-1}\left(\right.$ mean $0.43 \times 10^{8} \mathrm{t} \cdot \mathrm{year}^{-1}$ ) for 2004-2011. The sum of sediment yields of the Yangtze River at Cuntan and the Wu River at Wulong are representative of the inflowing sediment yield to the Three Gorge Reservoir. By comparing this sum with the sediment yield at Yichang, it is found that a systematic difference has occurred since 2003 when the first phase of the project operation started (Fig. 2), varying between 0.86 and 1.84 $\times 10^{8} \mathrm{t} \cdot$ year $^{-1}$ (mean $1.41 \times 10^{8} \mathrm{t} \cdot \mathrm{year}^{-1}$ ), which is less than the annual sediment deposition in the Three Gorge Reservoir (Fig. 2) and the mean value for the decade varied from 1342 to $1457 \times 10^{8}$ $\mathrm{m}^{3}$ (Table 1). Silt content varied normally during 1956-1980 with a mean value of $1.69 \mathrm{~kg} \cdot \mathrm{m}^{-3}$ for 1956-1970 and $1.65 \mathrm{~kg} \cdot \mathrm{m}^{-3}$ for 1971-1980. But, it significantly increased during 1981-2000 with a mean value of $1.85 \mathrm{~kg} \cdot \mathrm{m}^{-3}$ for $1981-1990$ and $1.99 \mathrm{~kg} \cdot \mathrm{m}^{-3}$ for $1991-2000$. However, it suddenly decreased to $1.08 \mathrm{~kg} \cdot \mathrm{m}^{-3}$ during 2001-2011, probably reflecting commence of operation of Ertan Reservoir in 1999 (Fig. 2).

\section{Effects of large dams on reducing fluvial sediment delivery}

Sediment trapping by dams is a well-documented mechanism explaining the abrupt reduction of downstream sediment yield (Walling, 2006). However, it is insufficient to explain the reduction of sediment yield in the Lower Jinsha River recorded at Pingshan. Since 1999, when the Ertan reservoir became operational, annual sediment yield at downstream Pingshan hydrometric station has decreased sharply. The mean annual value reduced from $2.95 \times 10^{8} \mathrm{t}$ for the pre-dam period of 1991-2000 to $1.54 \times 10^{8} \mathrm{t}$ for the post-dam period of 2001-2011. The reduced amount of sediment load at $1.41 \times 10^{8} \mathrm{t}$ is much larger than the annual average sediment load of $0.27 \times 10^{8} \mathrm{t}$ that has been discharged into the Ertan Reservoir.

The Ertan Reservoir is located near the outlet of the Yalong River which is the biggest tributary of the Jinsha River and has a storage capacity of $58 \times 10^{8} \mathrm{~m}^{3}$. The annual inflow runoff discharge is $5.27 \times 10^{8} \mathrm{~m}^{3}$, which accounts for $36.9 \%$ of the annual runoff discharge recorded at Pingshan. As a substantial proportion of the sediment load in the Jinsha River was transported by big floods, the impoundment of the Ertan Reservoir has great effects on retaining peak flood discharge and the sediment transportation capacity of Jinsha River below Ertan Reservoir will be significantly reduced.

A mechanism of sediment transportation capacity reduction is proposed to illustrate the effects of a large reservoir with unlimited storage volume on changes of sediment yields with time and distance in the downstream reaches (Fig. 3). For the downstream reaches with no sediment supply from local tributaries (Model I), it is assumed that sediment yield does not change with distance and the relationship between sediment yield and distance is a line parallel to the $\mathrm{X}$ axis. Impoundment of a large reservoir leads to an immediate sharp reduction of sediment yield and the yield will gradually increase with time and distance from the dam site, because sediment trapping efficiency decreases with time and sediment supply from channel bed erosion increases with distance. After a certain time, when the channel beds of the downstream segment are scoured to a base that is rigid or too coarse to supply sediment, the sediment yield in the downstream segment will return to the situation before the reservoir construction.

For a downstream segment with limited and uniform sediment supply from tributaries (Model II), it is assumed that sediment yield has uniform change with distance and the relationship between sediment yield and distance is an oblique line. As in Model I, impoundment of a large 
reservoir results in immediate sharp reduction of sediment yield and sediment yield will gradually increase with time and distance. After a certain time, the channel beds of the downstream segment are scoured to a base too rigid or too coarse to supply sediment.

For a downstream segment with a huge and uniform sediment supply from tributaries (Model III), it is assumed that sediment yield changes uniformly with distance and the relationship between sediment yield and distance is an oblique line, which is steeper than Model II. As in Models I and II, impoundment of a large reservoir results in an immediate sharp reduction of sediment yield, but the yield will rapidly increase with time and distance (steep gradient) because of the huge sediment supply from tributaries. Then the gradient will become gentle because of the limited sediment transportation capacity, which is greatly reduced by the dampening of the peak flood discharge by the reservoir impoundment. Beyond a certain distance downstream, the differences of the sediment yields before and after the reservoir impoundment at a point may be greater than the sediment trapped by the reservoir. This is different from Models I and II. After a certain time, the sediment yield in the downstream segment will return to the situation before the reservoir construction because of recovery of the sediment transport capacity due to geometric shape changes of the channels in the downstream segment.
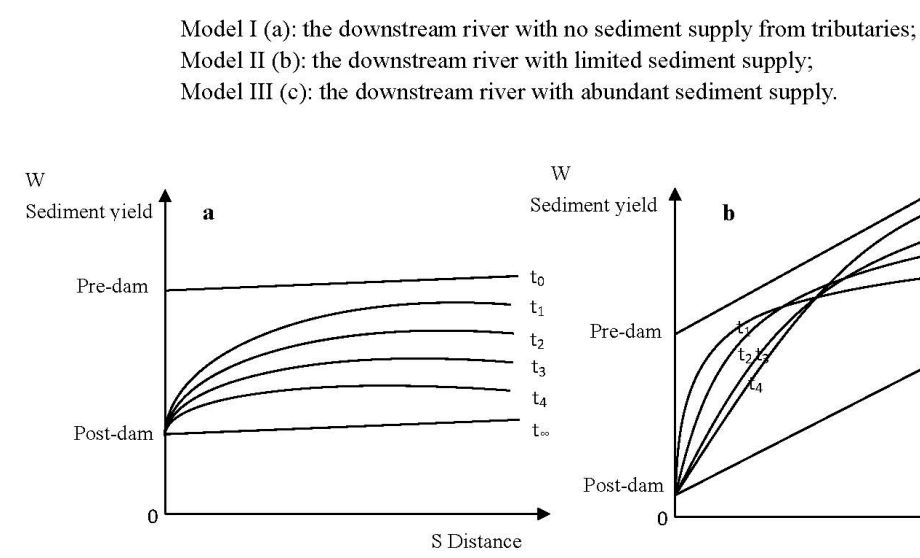

Model I (a): the downstream river with no sediment supply from tributaries; Model II (b): the downstream river with limited sediment supply;

Model III (c): the downstream river with abundant sediment supply.

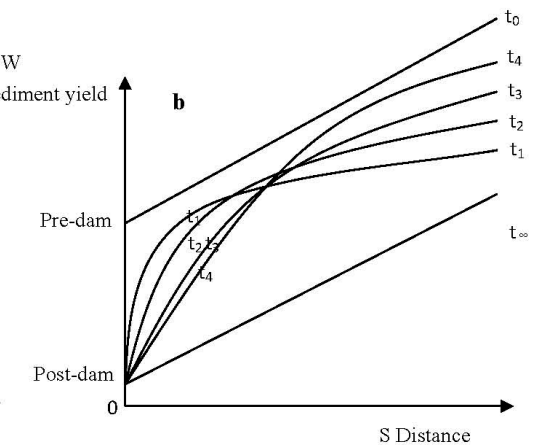

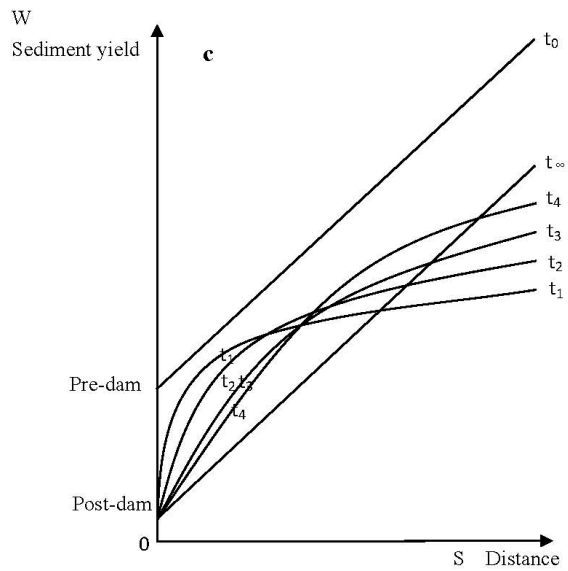

Fig. 3 Models to illustrate changes of sediment yields with time and distance in downstream segment below a large reservoir with unlimited storage volume: (a) Model I, (b) Model II, and (c) Model III.

\section{CONCLUSION}

Suspended sediment yields in the Upper Yangtze River and its four major tributaries have declined significantly during the past decades. Compared with 1956-1970, mean annual sediment yields during 2001-2011 were reduced by $84 \%$ in the Upper Yangtze River at Yichang, by $34 \%$ in the Jinsha River at Pingshan, by $84 \%$ in the Jialing River at Beibei, by $75 \%$ in the Wu River at Wulong, and by $48 \%$ in the Min River at Gaochang.

Linking the decadal changes of fluvial runoff discharges and suspended sediment yields since the 1950s to construction of large dams and the environment rehabilitation projects implemented since the 1970s, it can be concluded that dam construction has played a predominant role in the recent reduction of suspended sediment yields in the major tributaries, except for Jialing River where the environment rehabilitation projects have contributed considerably to the reduction of fluvial suspended sediment yields.

Suspended sediment yields in the Upper Yangtze River recorded at Yichang have significantly decreased since the 1999 due to the sudden drop of sediment yield from upstream Jinsha River. An abrupt decrease of suspended sediment load occurred in 2003 when the firstphase operation of the Three Gorges Reservoir was implemented. The total sediment silting in the reservoir during 2003-2011was estimated to be $12.63 \times 10^{8} \mathrm{t}$. 
Besides trapping sediment, a large reservoir has effects on reducing sediment transportation capacity in the downstream reaches because the reservoir impoundment dampens peak flood discharge. A proposed mechanism for sediment transport capacity reduction is able to explain the severe decrease of sediment yield in the downstream segment with huge sediment supply from tributaries, the amount of which may be greater than the sediment inflow to the reservoir. It applies to the suspended sediment yields of Jinsha River at Pingshan below the Ertan Reservoir.

Acknowledgements Financial support for this study was jointly provided by the National Natural Science Foundation of China (Grant 41171222) and the Chinese Academy of Sciences (Grant KZCX2-XB3-09).

\section{REFERENCES}

Dai S. B., et al. (2008) A preliminary estimate of human and natural contributions to the decline in sediment flux from the Yangtze River to the East China Sea. Quatern. Int. 1861, 43-54.

Lin Q. S., Li H. \& Yao S. M. (2010) Analysis on variation of runoff and sediment load in main stream of upper Yangtze River in recent period (in Chinese). Yangtze River 41(10), 5-8.

Tang Q., et al. (2013) Determining the relative contributions of climate change and multiple human activities to variations of sediment regime in the Minjiang River, China. Hydrol. Process. 27, 3547-3559.

Walling D. E. (2006) Human impact on land-ocean sediment transfer by the world's rivers. Geomorphology 79, $192-216$.

Walling D. E. \& Fang D. (2003) Recent trends in the suspended sediment loads of the world's rivers. Global Planet. Change 39, $111-126$.

Zhang X. B. \& Wen A. B. (2004) Current changes of sediment yields in the upper Yangtze River and its two biggest tributaries, China. Global Planet. Change 41, 221-227. 